\title{
SELECTION OF BUFFALO MILK LACTIC ACID BACTERIA WITH PROBIOTIC POTENTIAL
}

\section{SRI MELIA, YUHERMAN, JASWANDI, ENDANG PURWATI}

Department of Animal Science, Andalas University, Padang, 25171, Indonesia. Email: purwati17@ansci.unand.ac.id

Received: 18 January 2018, Revised and Accepted: 23 February 2018

\begin{abstract}
Objective: The aim of this research was to isolate and identify lactic acid bacteria using $16 \mathrm{~S}$ rRNA and evaluates their potential as probiotics.

Methods: The probiotic properties measured were resistance to low pH and to $0.3 \%$ and $0.5 \%$ bile salts, antimicrobial activity against pathogenic
\end{abstract} bacteria (Escherichia coli 0157:H7 and Staphylococcus aureus ATCC 25923), antibiotic resistance, and hydrophobicity.

Results: The lactic acid bacteria with optimal probiotic properties were isolated from buffalo milk and identified from a sample from Agam district (BMA 3.3) which was classified using BLAST analysis as a strain of Lactobacillus fermentum (L23).

Conclusion: Buffalo milk from this part of West Sumatera contains a strain of L. fermentum with has good probiotic properties.

Keywords: Lactic acid bacteria, Probiotic, Buffalo milk, Lactobacillus fermentum strain L23.

(C) 2018 The Authors. Published by Innovare Academic Sciences Pvt Ltd. This is an open access article under the CC BY license (http://creativecommons. org/licenses/by/4. 0/) DOI: http://dx.doi.org/10.22159/ajpcr.2018.v11i6.24809

\section{INTRODUCTION}

Probiotics are living microorganisms that provide health-promoting effects for their host. Before a bacterium can be said to be probiotic, it must meet several criteria, including the ability: To survive in the presence of acids and bile salts, to produce antimicrobial compounds, and to colonize the intestines and resist antibiotics [1]. Common probiotics are lactic acid bacteria and bifidobacteria, which are isolated from fermented products, digestive systems, feces, and human breast milk. Researchers have started to look at other potential sources of probiotics including buffalo milk. Some probiotics have already been isolated from buffalo milk, [2] isolated Lactobacillus acidophilus, Lactobacillus rhamnosus, and Bifidobacterium longum, all potential probiotics, from buffalo milk from Karnataka, India, but little information is available regarding potential probiotic bacteria in buffalo milk in West Sumatera where the animals are common.

Buffalo milk plays a significant role in satisfying the nutritional demands of humans in a number of developing countries [3]. Buffalo milk has a rich complex nutritional profile. However, in West Sumatera, it is rarely consumed in its raw state. Here, milk from swamp buffalo (Bubalus bubalis) is fermented in a bamboo tube for $48 \mathrm{~h}$ to produce Dadih. Dadih production occurs in several different areas throughout West Sumatra. If proven to have probiotic properties, more extensive use of this local dish could be encouraged to improve the health and nutritional status of people in this area who tend to be resistant to adopting non-traditional foods.

There is good reason to believe that West Sumatera buffalo milk might be such a source of probiotics [2]. Isolated L. acidophilus, L. rhamnosus, and B. longum are potential probiotics, from buffalo milk from Karnataka, India [4]. Isolated lactic acid bacteria from buffalo milk in Islamabad, namely, L. acidophilus, Lactobacillus delbrueckii ssp. bulgaricus, Lactococcus lactis ssp. cremoris, L. Lactis ssp. lactis, and Streptococcus thermophilus. Similarly, Sharma et al. [5], also found L. lactis in buffalo milk in India [6], found strains of Lactobacillus spp., isolated from buffalo, goat, and cow milk, had potential as probiotics. Previous research on the content of lactic acid bacteria from buffalo milk from Pampangan North Sumatera has been conducted by Rizqiati et al. [7] who found several isolates of lactic acid bacteria, namely,
Lactobacillus brevis, Lactobacillus paracasei, Lactobacillus penthouse, Lactobacillus planetarium, and L. lactis.

However, the probiotic potential of lactic acid bacteria contained in buffalo milk in West Sumatera has yet to be studied.

\section{METHODS}

Lactic acid bacteria isolated from buffalo milk from several districts in West Sumatera were obtained and were coded according to the area it was sourced from. These were screened for acid resistance and five isolates from different areas with acid resistance above 50\% were obtained, namely, those coded BMA 3.3 (Agam District), BMTD 7.2 (Tanah Datar District), BMP 1.1 (Limapuluh Kota District), BMS 1.1 (Solok District), and BMSJ 4.2 (Sijunjung District). The bacteria were then tested for probiotic properties after being grown in de Man, Rogosa, and Sharp (MRS) broth (Merck, Germany) for $24 \mathrm{~h}$ at $37^{\circ} \mathrm{C}$.

\section{Lactic acid bacteria resistance test against acid condition}

Effect of acidic conditions (pH 2) was tested using MRS broth (Merck) regulated with $\mathrm{HCl} 1 \mathrm{~N}$ and MRS broth (Merck, pH 5.7) as controls. Both media were inoculated with $1 \%$ isolate, at $37^{\circ} \mathrm{C}$ for $90 \mathrm{~min}$ and for $180 \mathrm{~min}$, and measured at $\mathrm{A}_{600 \mathrm{~nm}}[8]$.

\section{Lactic acid bacteria resistance against bile salts}

Testing with bile salts was conducted to see if the bacteria would survive in the human small intestine. Any probiotic must survive several hours in this part of the digestive system before it reaches the large intestine where its presence provides the health benefits for the host. $1 \%$ isolates were inoculated into MRS broth containing $0.3 \%$ and $0.5 \%$ bile salts (Oxgall, Merck, Germany) for $5 \mathrm{~h}$ at $37^{\circ} \mathrm{C}$. After $5 \mathrm{~h}$, the bacterial populations were measured at $\mathrm{A}_{600 \mathrm{~mm}}$ and compared to a control (without addition of bile salts). Results were recorded as the ratio of growth rate between the bile salts and controls at $A_{600 \mathrm{~nm}}[8,9]$.

\section{Antibacterial activity test against pathogens}

Modification of the well diffusion assay of Yang et al., Ayeni et al. [10,11] was used to test the antibacterial activity against pathogens Escherichia coli 0157:H7 and Staphylococcus aureus ATCC 25923. Cell-free supernatant derived from lactic acid bacteria that had been 
grown in MRS broth for $24 \mathrm{~h}$ at $37^{\circ} \mathrm{C}$, in anaerobic conditions and then centrifuged at $10,000 \mathrm{rpm}$ for $5 \mathrm{~min}$ at $4^{\circ} \mathrm{C} .50 \mathrm{~mL}$ of the supernatant was placed in a well on which pathogenic bacteria on MHA medium (Mueller Hinton Agar, Merck) were growing. The size of the inhibition zone indicating antibacterial activity of the isolate was measured after $24 \mathrm{~h}$

\section{Antibiotic resistance test}

Isolates of lactic acid bacteria were tested for resistance to antibiotics using the method of the Clinical and Laboratory Standards Institute [12]. Antibiotics used in this study were ampicillin $(10 \mu \mathrm{g})$, chloramphenicol $(30 \mu \mathrm{g})$, erythromycin $(15 \mu \mathrm{g})$, penicillin $(10 \mu \mathrm{g})$, and tetracycline $(30 \mu \mathrm{g})$. These were placed on MRS agar plates (Merck) which already contained the lactic acid bacteria. The plates were then incubated anaerobically at $37^{\circ} \mathrm{C}$, for $24 \mathrm{~h}$. The inhibition zone diameter was measured. The results were categorized as resistance (R), intermediates (I), and sensitive (S) according to the standard inhibition diameter for each antibiotic.

\section{Hydrophobicity test}

Measurements to determine the cell-surface hydrophobicity can be conducted in vitro by measuring the percentage adherence of microbial cells to solvents such as xylene, toluene, or n-hexadecane [13]. Xylene, toluene, and n-hexadecane can be used because they are non-polar and their hydrophobic properties help interact with the hydrophobic microbial surfaces.

The hydrophobicity test was conducted using xylene to determine the adhesive properties of lactic acid bacteria isolates in vitro [14]. Lactic acid bacteria isolates were incubated (anaerobically) at $37^{\circ} \mathrm{C}$ for 18-22 $\mathrm{h}$ and centrifuged at 10,700 rpm for $5 \mathrm{~min}$ [15]. After that, the bacterial cells were washed twice with PBS pH 7 and OD $600 \mathrm{~nm}$ (A0) was read. A suspension of $3 \mathrm{~mL}$ lactic acid bacteria was mixed with $1 \mathrm{~mL}$ of xylene for $60 \mathrm{~s}$, then incubated for $2 \mathrm{~h}$ at $37^{\circ} \mathrm{C}$. The aqueous phase at the bottom was taken and OD $600 \mathrm{~nm}$ measured (A1). The resulting hydrophobicity is calculated by subtracting A1 divided by A0 from A0, then multiplying the result by $100 \%$ [16].

\section{Identification of lactic acid bacteria using 16S rRNA sequencing} Lactic acid bacteria isolates were cultured in MRS broth at $37^{\circ} \mathrm{C}$ for $24 \mathrm{~h}$. Isolation of genomic DNA was carried out using Extrap Soil DNA Kit Plus Ver.2. Polymerase chain reaction (PCR) amplification of the isolates' 16S rRNA using a 16S rRNA fragment gene of $\sim 1.5 \mathrm{~KB}$ was conducted using universal primers 27 F: (5'- GAGTTTGATCCTGGCTAG-3') and 1525 R:(5'-AGAAAGGAGGTGATCCAGCC-3'). Initial denaturation at $95^{\circ} \mathrm{C}$ for 5 min with 25 cycles was followed by denaturation at $94^{\circ} \mathrm{C}$ for $1 \mathrm{~min}$, then annealing at $56^{\circ} \mathrm{C}$ for $1 \mathrm{~min}$, extension at $72^{\circ} \mathrm{C}$ for $1.5 \mathrm{~min}$, and final extension at $72^{\circ} \mathrm{C}$ for $7 \mathrm{~min}$. The resulting DNA was separated out using electrophoresis at $100 \mathrm{~V}$ for $21 \mathrm{~min}$, using a $1 \%$ agarose in $\times 1 \mathrm{TAE}$ buffer. Then, a gel documentation system was used to produce an image of the bands in the gel. Purification was conducted using a fast gene gel/PCR extraction kit (Nippon Genetics, Germany), and the resulting sequences analyzed using the BLAST program at the NCBI gene bank database that can be viewed at http://blast.ncbi.nlm.nih.gov/Blast.cgi. Sequence alignments were prepared using Bioedit application, and the phylogenetic tree was created with the MEGA application 6.

\section{RESULTS AND DISCUSSION}

Lactic acid bacteria resistance to acid conditions

Any effective probiotic must survive passage through the digestive tract so must be resistant to the acidic conditions of the stomach of $\mathrm{pH}$ of 1.5-3.5, which are caused by the secretion of gastric juice.

Fig. 1 shows the resistance of lactic acid bacteria to $\mathrm{pH} 2$ (gastric acid $\mathrm{pH})$ at $90 \mathrm{~min}$ and $180 \mathrm{~min}$. The BMA 3.3 isolate, which was incubated at pH 2 and $90 \mathrm{~min}$, showed resistance up to $95.018 \%$ after $90 \mathrm{~min}$ and $73.944 \%$ at $180 \mathrm{~min}$. This decrease of $23 \%$ was quite small compared to other isolates. For example, BMS 1.1 experienced a $37 \%$ decrease indicating lower resistance to acid. This result for BMA 3.3 is even higher than the lactic acid bacteria isolated from milk and cattle dung samples by Jain et al. [13], which is regarded as a potential probiotic because it can survive at pH 2 (56.93-80.88\%) and pH 3 (61.44-81.25\%). While the lactobacillus investigated by Singh et al. [17] showed a tolerance to acid at pH 2 (46.47-79.74\%).

\section{Lactic acid bacteria resistance against bile salts}

Effective probiotics must also be able to thrive in the alkaline $\mathrm{pH}$ of the small intestine which is affected by bile salts secreted by the liver. Bile reduces the number of bacteria by destroying their cell walls. The concentration of bile salts in the human body is $0.3-0.5 \%$ [18- 20], and several probiotic bacteria have been shown to survive these concentrations [21], found Lactobacillus oris HM168 isolated from breast milk, survives at $0.3 \%$ and $0.5 \%$ bile salt for $5 \mathrm{~h}$. Likewise, the strain of lactic acid bacteria isolated from buffalo milk from Karnataka, India, was able to survive in concentrations of $0.3 \%$ and $0.5 \%$ bile salts, but this was not sustained at 1\% [2]. The five isolates of lactic acid bacteria were tested for bile salt resistance of $0.3 \%$ and $0.5 \%$, for $5 \mathrm{~h}$.

Fig. 2 demonstrates that the highest resistance to bile salts at $0.3 \%$ is shown by the BMSJ 4.2 isolate, followed by BMS 1.1, BMA 3.3, BMP 1.1, and BMTD 7.2. However, at $0.5 \%$ bile salt, the BMA isolate 3.3 showed the highest resistance experiencing the lowest decrease of all isolates (13\%). BMA 3.3's 5-26\% decrease due to acid followed by a 35-40\% decrease after exposure to bile salts falls within the criteria quoted by Bezkorovainy [22] that to be a useful probiotic in the human digestive system a bacterium's resistance to gastric acid and bile salts should be between $20 \%$ and $40 \%$

\section{Antibacterial activity against pathogens}

Effective probiotics must be antimicrobial that is they help to control pathogenic bacteria in the digestive tract. The ability of lactic acid bacteria to inhibit the growth of pathogenic bacteria is influenced by their ability to produce antimicrobial compounds such as bacteriocin [1] and organic acids. Bacteriocin actively attacks Grampositive pathogenic bacteria such as Listeria monocytogenes and $S$. aureus and also some Gram-negative bacterial pathogens [23,24]. For example, Lactobacillus pentosus and Lactobacillus plantarum from

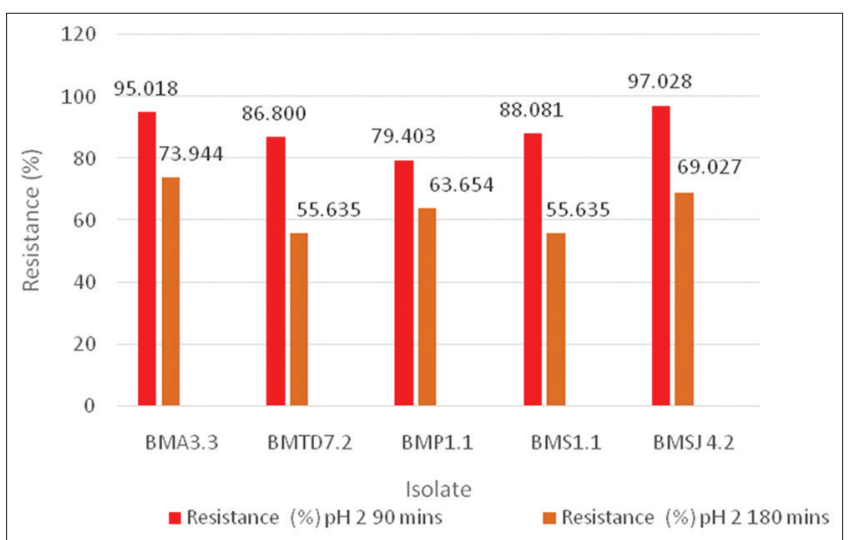

Fig. 1: Lactic acid bacteria resistance to acid conditions

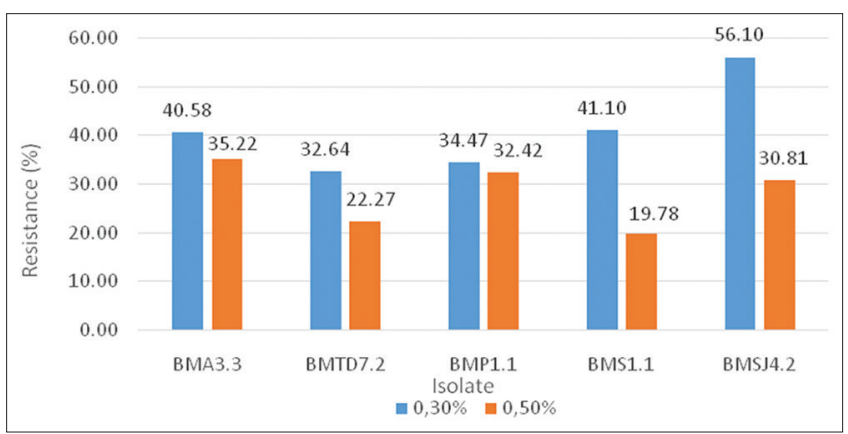

Fig. 2: Lactic acid bacteria resistance against bile salt 
okara was found to have antimicrobial activity against E. coli, S. aureus, and L. monocytogenes [25].

Table 1 summarizes that all lactic acid bacteria isolates were capable of inhibiting the growth of pathogenic bacteria. The highest antibacterial activity against $E$. coli $0157:$ H7 was demonstrated by BMA 3.3 and BMS 1.1. The highest antibacterial activity against $S$. aureus ATCC 25923 was from BMP 1.1. Overall, BMA 3.3 shows the most promising antibacterial properties against both common pathogens. The antibacterial activity of BMA 3.3 isolates against S. aureus ATCC 25923 and E. coli 0157:H7 was lower than that of Lactobacillus fermentum isolated from buffalo milk by Jain et al. [13], which had higher antibacterial activity against $S$. aureus $(20.34 \pm 0.02 \mathrm{~mm})$. However, the strain does show a significant protective effect against both $E$. coli and $S$. aureus.

\section{Antibiotic resistance of lactic acid bacteria}

The sensitivity of lactic acid bacteria to antibiotics can be seen in Table 2 . All lactic acid bacteria isolates were resistant to ampicillin and sensitive to tetracycline and chloramphenicol, except BMP 1.1 and BMSJ 4.2 isolates which showed intermediate susceptibility to chloramphenicol. Apart from BMS 1.1, all isolates were resistant to both erythromycin and penicillin [26], also found that lactic acid bacteria they isolated were resistant to erythromycin and penicillin.

\section{Hydrophobicity of lactic acid bacteria}

Effective probiotics must be able to colonize the digestive tract to provide protection against pathogenic microbes. Lactobacilli with hydrophobic cell surfaces can do this as they attach to the host gastrointestinal tract.

According to Sánchez-Ortiz et al. [27], 30\% is considered low hydrophobicity (adhesion to p-xylene), $30-60 \%$ is medium, and $60 \%$ is high hydrophobicity. Hydrophobicity percentages can be seen in Fig. 3. Medium hydrophobicity was measured for BMA 3.3 and BMTD 7.2. The highest hydrophobicity was shown by BMA 3.3 (55.492 \pm $0.823)$. This value is lower than the results of the research of Tokath et al. [28] who found hydrophobicity percentages from L. brevis MF105 of $97.96 \%$, L. plantarum MF265 of $82.41 \%$, L. brevis MF949 of $67.29 \%$, and L. brevis MF493 of $62.36 \%$. These four isolates were categorized as probiotics.

\section{Identification of lactic acid bacteria from $16 \mathrm{~S}$ rRNA}

Of the five isolates of lactic acid bacteria from buffalo milk from different regions, isolate BMA 3.3 was selected as being the most promising as it has the highest resistance to acid and bile salts, highest antimicrobial activity, good antibiotic resistance, and highest hydrophobicity. 16S rRNA sequence analysis identified this isolate as L. fermentum strain L2.3 (Figs. 4 and 5). Interestingly, this bacterial strain appears to be identical to one of the lactic acid bacteria that were isolated from buffalo milk in Mumbai [29]. L. fermentum L2.3 has also been found in the human vagina and found to be protective against E. coli [30]. Almost $48 \%$ of the lactic acid bacteria in West Sumatran buffalo milk were L. fermentum followed by L. acidophilus (34\%), L. viridescens (8\%), L. brevis (5\%), and L. gasseri (4\%). This combination differs from that found in buffalo milk from Karnataka, India, by Shafakatullah and Chandra [2] who isolated potential probiotic lactic acid bacteria; L. rhamnosus and B. longum along with L. acidophilus.

\section{CONCLUSION}

The results identified one lactic acid bacteria isolated from a sample of swamp buffalo milk harvested in Agam district that showed high probiotic potential. Of all the isolates, BMA 3.3 had the best ability to survive at low $\mathrm{pH}$, resist bile salts. It effectively inhibited the growth of pathogenic bacteria (E. coli 0157: H7 and S. aureus ATCC 25923) and was resistant to three of the five most commonly used antibiotics and had medium hydrophobicity. This lactic acid bacterial strain was identified as L. fermentum strain L23. This isolate has potential as a natural addition in the production of fermented milk-based foods to enhance their health value.

\section{ACKNOWLEDGMENT}

Authors express gratitude to the Institute of Research and Community service, Andalas University for the Research Professor Cluster Scheme Grant No. 53/UN.16.17/PP.HGB/LPPM/2017 and the Animal Product Technology Laboratory and the Animal Biotechnology Laboratory in the Faculty of Animal Science, Andalas University, who provided facilities for research.

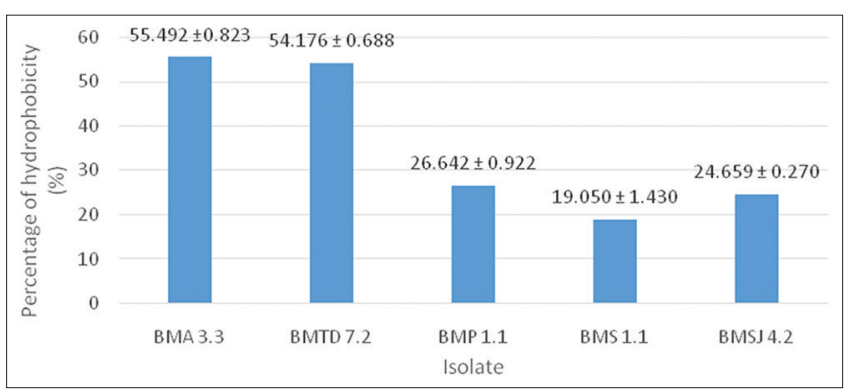

Fig. 3: Hydrophobicity percentage of lactic acid bacteria

Table 1: Antibacterial activity against pathogens

\begin{tabular}{lll}
\hline Isolate & \multicolumn{2}{l}{ Inhibition zone $(\mathbf{m m})$} \\
\cline { 2 - 3 } & E. coli 0157:H7 & S. aureus ATCC 25923 \\
\hline BMA 3.3 & $16 \pm 0.82$ & $19 \pm 0.47$ \\
BMTD 7.2 & $15 \pm 0.82$ & $15 \pm 0.94$ \\
BMP 1.1 & $12 \pm 0.00$ & $18 \pm 0.82$ \\
BMS 1.1 & $16 \pm 0.82$ & $16 \pm 0.47$ \\
BMSJ 4.2 & $9 \pm 0.94$ & $14 \pm 0.47$ \\
\hline
\end{tabular}

The value is expressed as the mean \pm standard deviation; $n=3$, E. coli: Escherichia coli, S. aureus: Staphylococcus aureus

TCGAACGCGTTGGCCCAATTGATTGATGGTGCTTGCACCTGATTGATTTTGGTCGCCAACGAGTGGCGG
ACGGGTGAGTAACACGTAGGTAACCTGCCCAGAAGCGGGGGACAACATTTGGAAACAGATGCTAATA
CCGCATAACAACGTTGTTCGCATGAACAACGCTTAAAAGATGGCTTCTCGCTATCACTTCTGGATGGA
CCTGCGGTGCATTAGCTTGTTGGTGGGGTAACGGCCTACCAAGGCGATGATGCATAGCCGAGTTGAGA
GACTGATCGGCCACAATGGGACTGAGACACGGCCCATACTCCTACGGGAGGCAGCAGTAGGGAATCT
TCCACAATGGGCGCAAGCCTGATGGAGCAACACCGCGTGAGTGAAGAAGGGTTTCGGCTCGTAAAGC
TCTGTTGTTAAAGAAGAACACGTATGAGAGTAACTGTTCATACGTTGACGGTATTTAACCAGAAAGTC
ACGGCTAACTACGTGCCAGCAGCCGCGGTAATACGTAGGTGGCAAGCGTTATCCGGATTTATTGGGCG
TAAAGAGAGTGCAGGCGGTTTTCTAAGTCTGATGTGAAAGCCTTCGGCTTAACCGGAGAAGTGCATCG
GAAACTGGATAACTTGAGTGCAGAAGAGGGTAGTGGAACTCCATGTGTAGCGGTGGAATGCGTAGAT
ATATGGAAGAACACCAGTGGCGAAGGCGGCTACCTGGTCTGCAACTGACGCTGAGACTCGAAAGCAT
GGGTAGCGAACAGGATTAGATACCCTGGTAGTCCATGCCGTAAACGATGAGTGCTAGGTGTTGGAGG
GTTTCCGCCCTTCAGTGCCGGAGCT

Fig. 4: Nucleotide sequence of Lactobacillus fermentum strain L23 
Table 2: Sensitivity of lactic acid bacteria isolates to different antibiotics (diameter of the inhibition zone in mm)

\begin{tabular}{|c|c|c|c|c|c|}
\hline \multicolumn{6}{|c|}{ Antibiotics } \\
\hline Isolate & Ampicillin & Chloramphenicol & Erythromycin & Penicillin & Tetracycline \\
\hline BMA 3.3 & $5 \pm 0.82(\mathrm{R})$ & $21 \pm 0.47(S)$ & $12 \pm 1.25(\mathrm{R})$ & $8 \pm 1.70(\mathrm{R})$ & $24 \pm 2.62(S)$ \\
\hline BMP 1.1 & $3 \pm 0.94(\mathrm{R})$ & $14 \pm 1.70$ (I) & $3 \pm 0.82(\mathrm{R})$ & $4 \pm 0.47(\mathrm{R})$ & $22 \pm 1.41(\mathrm{~S})$ \\
\hline BMS 1.1 & $12 \pm 0.47(\mathrm{R})$ & $27 \pm 0.47(S)$ & $24 \pm 1.25(\mathrm{~S})$ & $16 \pm 1.41(\mathrm{~S})$ & $25 \pm 1.41(\mathrm{~S})$ \\
\hline BMSJ 4.2 & $0(\mathrm{R})$ & $18 \pm 0.94(\mathrm{I})$ & $0(\mathrm{R})$ & $0(\mathrm{R})$ & $28 \pm 0.94(S)$ \\
\hline
\end{tabular}

R: Resistant, I: Intermediate, S: Sensitive. The value is expressed as the mean \pm , standard deviation; $\mathrm{n}=3$

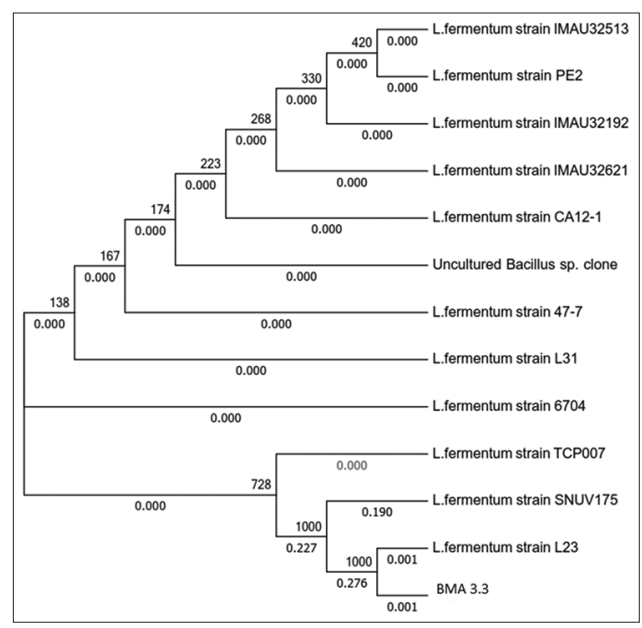

Fig. 5: Phylogenetic tree of Lactobacillus fermentum strain L23

\section{AUTHOR'S CONTRIBUTION}

Sri Melia designed, conducted, and wrote up the search, and Yuherman, Jaswandi, and Endang Purwati provided guidance and helped with manuscript revision.

\section{CONFLICT OF INTERESTS}

There is no conflict of interest.

\section{REFERENCES}

1. FAO/WHO. Probiotics in Food, Health and Nutritional Properties and Guidelines for Evaluation in FAO Food and Nutritional Paper. Roma, Italy: $\mathrm{FAO} / \mathrm{WHO} ; 2006$. p. 85

2. Shafakatullah N, Chandra M. Screening of raw buffalo's milk from Karnataka for potential probiotic strains. Res J Rec Sci 2014;3:2502.

3. Salam MH, Shibiny SE. A comprehensive review on the composition and properties of buffalo milk. Dairy Sci Tehcnol 2011;91:663-99.

4. Aziz T, Khan H, Bakhair SM, Naurin M. Incidence and relative abundance of lactic acid bacteria in raw milk of buffalo, cow and sheep. Anim Plant Sci 2009;19:168-73.

5. Sharma R, Sanodiya BS, Thakur GS, Jaiswal P, Pal S, Bisen PS. Characterization of lactic acid bacteria from raw milk sample of cow, goat, sheep, camel and buffalo with special elucidation to lactic acid production. Br Microbiol Res J 2013;3:743-52.

6. Tembekar DH, Bhutada SA, Choundhary SD, Khond MD. Assessment of potential probiotic isolated from milk of domestic animals. J Appl Biosci 2009; 15:815-9.

7. Rizqiati H, Sumantri C, Noor RR, Damayanthi E, Rianti EI. Characteristic of Indigenous probiotic from river buffalo milk in North Sumatera Indonesia. Int J Sci Basic Appl 2016;22:113-20.

8. Rubio R, Jofré A, Martín B, Aymerich T, Garriga M. Characterization of lactic acid bacteria isolated from infant faeces as potential probiotic starter cultures for fermented sausages. Food Microbiol 2014;38:303-11.

9. Vinderola CG, Reinheimer JA. Lactic acid and probiotic bacteria: A comparative "in vitro" study of probiotic characteristics and biological barrier resistance. Food Res Int 2003;36:895-904

10. Yang E, Fan L, Jiang Y, Doucette C, Fillmore S. Antimicrobial activity of bacteriocin-producing lactic acid bacteria isolated from cheeses and yogurts. AMB Express 2012;2:48.
11. Ayeni FA, Adeniyi BA, Ogunbanwo ST, Tabasco R, Paarup T, Pelaez C, et al. Inhibition of uropathogens by lactic acid bacteria isolated from dairy foods and cow's intestine in western Nigeria. Arch Microbiol 2009;191:639-48.

12. Clinical and Laboratory Standards Institute (CLSI). Performance Standard for Antimicrobial Disk Susceptibility Test 2009: M2-A10. Wayne, PA, USA: CLSI; 2009.

13. Jain N, Mehta A, Bharti V. Screening, characterization, and in vitro evaluation of probiotic of Lactobacillus strains. Asian J Pharm Clin Res 2017; 10:288-93.

14. Collado MC, Surono I, Meriluoto J, Salminen S. Indigenous dadih lactic acid bacteria: Cell-surface properties and interactions with pathogens. J Food Sci 2007;72:M89-93.

15. Yotpanya P, Panya M, Enchanil C, Suebwongso N, Namwat W, Thaw H, et al. Probiotic characterization of lactic acid bacteria isolated from infant feces and its application for the expression of green fluorescent protein. Malays J Microbiol 2016;12:76-84

16. Meira SM, Helfer VE, Velho RV, Lopes FC, Brandelli A. Probiotic potential of lactobacillus spp. Isolated from brazilian regional ovine cheese. J Dairy Res 2012;79:119-27.

17. Singh TP, Kaur G, Malik RK, Schillinger U, Guigas C, Kapila S, et al. Characterization of intestinal lactobacillus reuteri strains as potential probiotics. Probiotics Antimicrob Proteins 2012;4:47-58.

18. Dunne C, O'Mahony L, Murphy L, Thornton G, Morrissey D, O'Halloran $\mathrm{S}$, et al. In vitro selection criteria for probiotic bacteria of human origin: Correlation with in vivo findings. Am J Clin Nutr 2001;73:386S-392S.

19. Zavaglia AG, Kociubinsky G, Pérez P, de Antoni G. Isolation and characterization of bifidobacterium strains for probiotic formulation. J Food Protec 1998;61:865-73.

20. Gilliland SE, Staley TE, Bush LJ. Importance of bile tolerance of Lactobacillus acidophilus used as a dietary adjunct. J Dairy Sci 1984;67:3045-51.

21. Anandharaj M, Sivasankari B. Isolation of potential probiotic lactobacillus oris HMI68 from mother's milk with cholesterol-reducing property. J Biosci Bioeng 2014;118:153-9.

22. Bezkorovainy A. Probiotics: Determinants of survival and growth in the gut. Am J Clin Nutr 2001;73:399S-405S

23. Melia S, Purwati E, Yuherman, Jaswandi, Aritonang SM, Silaen M. Characterization of the antimicrobial activity of lactic acid bacteria isolated from buffalo milk in West Sumatera (Indonesia) against Listeria monocytogenes. Pak J Nutr 2017;16:645-50.

24. Cotter PD, Hill C, Ross RP. Bacteriocins: Developing innate immunity for food. Nat Rev Microbiol 2005;3:777-88.

25. Aritonang SN, Roza E, Rossy E, Purwati E, Husmaini. Isolation and identification of lactic acid bacteria from okara and evaluation of their potential as candidat probiotics. Pak J Nutr 2017;16:618-28.

26. Sadrani H, Dave J, Vyas BR. Screening potential Lactobacillus Strains isolated from fermented foods, fruits and of human origin. Asian J Pharm Clin Res 2014;7:216-25.

27. Sánchez-Ortiz AC, Luna-González A, Campa-Córdova ÁI, EscamillaMontes R, Flores-Miranda Mdel C, Mazón-Suástegui JM. Isolation and characterization of potential probiotic bacteria from pustulose ark (Anadara tuberculosa) suitable for shrimp farming. Lat Am J Aquat Res 2015;43:123-36

28. Tokatlı M, Gülgör G, Bağder Elmacı S, Arslankoz İsleyen N, Özçelik F. In vitro properties of potential probiotic indigenous lactic acid bacteria originating from traditional pickles. Biomed Res Int 2015;2015:315819.

29. Mithun S, Dipak V, Sheela S. Isolation and identification of Lactobacilli from raw milk samples obtained from Aarey milk colony. Int J Sci Res Publ 2015;5:1-5

30. Pascual L, Francisco R, Walter G, Isabel B. Vaginal colonization and activity of probiotic bacterium Lactobacillus fermentum L23 in a murine model of vaginal tract infection. J Med Microbiol 2010;59:360- 4. 